\title{
HIGHLIGHTS
}

HIGHLIGHT ADVISORS

ANTON BERNS

NETHERLANDS CANCER INSTITUTE, AMSTERDAM, THE NETHERLANDS

\section{PETER BOYLE}

EUROPEAN INSTITUTE OF ONCOLOGY, MILAN, ITALY

\section{PETER CARMELIET}

CATHOLIC UNIVERSITY LEUVEN, LEUVEN, BELGIUM

\section{RON DEPINHO}

HARVARD MEDICAL SCHOOL, BOSTON, MA, USA

STEPHEN W. FESIK

ABBOTT LABORATORIES, ABBOTT PARK, IL, USA

\section{ELI GILBOA}

DUKE UNIVERSITY MEDICAL CENTER, DURHAM, NC, USA

\section{TOMAS LINDAHL}

IMPERIAL CANCER RESEARCH FUND, HERTFORDSHIRE, UK

\section{LANCE LIOTTA}

NATIONAL CANCER INSTITUTE, BETHESDA, MD, USA

\section{JANET D. ROWLEY}

UNIVERSITY OF CHICAGO MEDICAL CENTER, CHICAGO, IL, USA

\section{DAVID SIDRANSKY}

JOHNS HOPKINS UNIVERSITY SCHOOL OF MEDICINE, BALTIMORE, MD, USA

\section{JÜRG TSCHOPP}

UNIVERSITY OF LAUSANNE, EPALINGES, SWITZERLAND

\section{BERT VOGELSTEIN}

JOHNS HOPKINS ONCOLOGY CENTER, BALTIMORE, MD, USA

\section{ROBERT A. WEINBERG}

WHITEHEAD INSTITUTE FOR BIOMEDICAL RESEARCH, CAMBRIDGE, MA, USA

\section{SAVIO WOO}

MOUNT SINAI SCHOOL OF MEDICINE, NEW YORK, NY, USA

\section{TRANSLOCATIONS \\ Rare simplicity}

Single genetic lesions underlying transformation are seldom found in epithelial cancers because of the genetic complexity of the disease. However, Tognon et al. now report a translocation event that forms a dominantly acting oncogene and causes a rare form of breast cancer secretory breast carcinoma (SBC).

Secretory carcinoma accounts for less than $1 \%$ of all breast cancers and occurs in patients as young as 3 years old - patients are usually cured, but a mastectomy or chemotherapy is often required. It is generally accepted that specific fusion genes are associated with specific tumour types, but when the authors saw that a translocation which they had previously identified in paediatric mesenchymal tumours - was the only karyotypic abnormality in an SBC in one 6-year-old patient, they decided to investigate other cases.

The translocation - between the ETV6 transcription factor on chromosome 12 and the protein tyrosine kinase domain of the neurotrophin-3 receptor NTRK3 on chromosome 15 - results in constitutive activation of wild-type NTRK3, which activates the RASmitogen-activated protein kinase and the phosphatidylinositol 3-kinaseAKT pathways for mitogenesis and cancer survival.

The authors detected ETV6NTRK3 fusion transcripts in tumour specimens from 11 out of 12 further patients with SBC, all of whom had the identical breakpoint sequence. Dual-colour fluorescence in situ hybridization ( F I S H ) analys is s h o w e d that all samples of SBC that were available for analysis were positive for the fusion gene. By contrast, no transcripts were found in 49 out of 50 cases of typical infiltrating ductal carcinoma - of which SBC is a rare subtype.

So, these findings indicate that the ETV6-NTRK3 gene fusion is a non-random rearrangement in SBC, but does the translocation product (EN) cause transformation? Tognon and colleagues transfected two immortalized non-transformed mouse epithelial cell lines - the Scg6 cell line has mesenchymal features, and Eph4 has a stable epithelial phenotype - with an ETV6-NTRK3 retroviral construct. Both cell lines expressed the construct and showed a transformed phenotype, whereas cells transfected with vector alone did not. In addition, when these cells were injected into nude mice, the EN-expressing cells formed tumours, whereas the cells transfected with vector alone did not. Histopathology showed that the original phenotype was

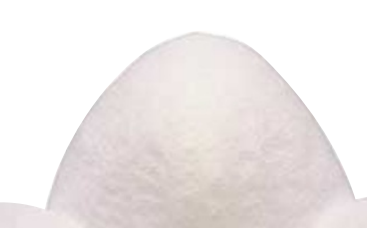

